\title{
Mining from a conflicting to a collaborative activity: Review of literature
}

\author{
Jan Feyen ${ }^{1}$, Patricio Crespo ${ }^{2}$, Rolando Célleri ${ }^{2}$ \\ ${ }^{1}$ Dirección de Investigación de la Universidad de Cuenca (DIUC), Av. 12 de Abril s/n, Cuenca, \\ Ecuador. \\ ${ }^{2}$ Departamento de Recursos Hídricos y Ciencias Ambientales (iDRHICA) \& Facultad de Ciencias \\ Agropecuarias, Universidad de Cuenca, Av. 12 de Abril s/n, Cuenca, Ecuador.
}

Autor para correspondencia: patricio.crespo@ucuenca.edu.ec

Fecha de recepción: 3 de marzo de 2013 - Fecha de aceptación: 23 de septiembre de 2015

\begin{abstract}
This article states that the confrontational attitude between local communities pushed by lobbying groups, eventually with the support of local governments, and mining companies can be turned into a corporate communication and cooperation model. Several of the large mining companies recently adopted a corporate business model in which ample room is given to the social and economic desires of the communities living nearby mining sites. Proposed actions that contribute to a collaborative attitude are the investment of time in the setting up of a communication model, the negotiation of impact and benefit agreements, involving community members in the organization and exploitation of services and the provision of goods, training of locals in conservation and restoration techniques and related technologies, and making available infrastructure and equipment as to enable locals developing economic activities which they independently can continue after mine closure. Involving the local scientific community, eventually in association with environmentalists, in activities of monitoring, mitigation, remediation and restoration helps this sector to develop capacity which will be beneficial in educational and research related programs. Governments' participation will culminate in a better legal framework and the development of more efficient protocols for the verification if mining is conducted in an ethical, social and environmental sound manner.
\end{abstract}

Keywords: Mining, corporate model, communication, collaboration, environmental impacts, mitigation, remediation, restoration, Ecuador.

\section{RESUMEN}

Este artículo contrapone la actitud de confrontación entre las comunidades locales impulsadas por grupos de presión, en algunos casos con el apoyo de los gobiernos locales y las empresas mineras que pueden transformar su relación siguiendo un modelo de comunicación y cooperación empresarial. Varias de las grandes empresas mineras han adoptado recientemente un modelo de negociación corporativa, en el cual se considera un amplio espacio para tomar en cuenta las aspiraciones sociales y económicas de las comunidades que habitan en sectores de influencia de los proyectos mineros. Acciones propuestas que contribuyen a una actitud de colaboración son la inversión de tiempo en la creación de un modelo de comunicación, la negociación de acuerdos de impacto y beneficio mutuo, la participación de miembros de la comunidad en la organización y explotación de los servicios y el suministro de bienes, la capacitación de los comuneros en conservación y técnicas de restauración y las tecnologías relacionadas, y dotar de infraestructura y equipamiento que permita que las comunidades desarrollen actividades económicas independientes que se puedan mantener después del cierre de la mina. La participación de la comunidad científica local, eventualmente en asociación con los ecologistas, en las actividades de monitoreo, mitigación, rehabilitación y restauración ayudará a este sector a desarrollar las capacidades, lo cual será beneficioso para dar soporte a los programas educativos y de investigación relacionados a la temática. La participación de los gobiernos nacionales 
está relacionada a mejorar el marco legal y al desarrollo de protocolos de monitoreo más eficientes que permitan verificar si la mina se desarrolla de manera ética, social y ambientalmente responsable.

Palabras clave: Minería, modelo corporativo, comunicación, colaboración, impactos ambientales, mitigación, remediación, restauración, Ecuador.

\section{CONFRONTATION OF FUNDAMENTALLY DIFFERENT PHILOSOPHIES}

As stated by Williams (1990) the debate over mining is poisoned by the confrontation of fundamentally different philosophies. At issue is whether mineral resources should be extracted and exploited - or revered and preserved? Opponents of mining contend extracting natural resources from the earth is a crude and destructive method of making money. Environmentalists claim that mineral mines heavily destroy the environment using chemicals like cyanide to leach gold from crushed ore, a technology that has transformed even unprofitable mines into rentable enterprises (McGoll, 1980; Fields, 2006; Kumah, 2006). Once the gold is removed, the remaining material is dumped and effluent of the chemical-based extraction process pollutes regional water resources. In short, environmentalists state that mining cause immeasurable environmental damage (Tarras-Wahlberg et al., 2001; Mudd, 2007). They also argue that until recent little to no attention has been given to the restoration of the affected environment. Other critics state that mining generates housing shortage, sharp intensification in traffic, increases crime and prostitution, drives up the costs of local drug and alcohol rehabilitation programs, among other social impacts (Pick et al., 2003).

In general, large mining projects are situated in rural areas, coexisting with local communities which often are marginalized from the development processes. This situation heavily contributes to the antagonistic feelings to mining companies and governments. The latter inspired by the free market and trade philosophy incline supporting mine companies to increase foreign exchanges (Hilson, 2002; Bebbington et al., 2008). The philosophy of the local people, who view themselves as the guardians of the land and the natural resources, consider the land as their property and according to this way of thinking no one has the right to take the land and exploit its resources. Probably the main concern of the villagers is that mining not really contributes to the development of the communities. According to them, multinationals and governments steal the wealth while destroying the land, rivers and the environment and leaving the people in misery (Haarstad \& Floysand, 2007). Another cause of resistance to mining is the potential loss of sovereignty (Downing et al., 2002). The frustration and the growing opposition of local communities are also fed by the non-existence of appropriate laws to protect the environment and if laws do exist by the failure of the local and national governments to fully implement them.

Mining proponents state that the society has the right to develop natural resources for the betterment of all people. The liberalization of investment regimes has turned Latin America over the last 20 years into the main target of world's mining investment, capturing between 25 and $30 \%$ of the global budget (González Zenteno, 1999). This translates into a steady increase in the region's share of worldwide mineral and metal production, a trend which likely continues given Latin America's countries competitiveness and global consumption forecasts. Furthermore, it is recognized that mining is a major customer of other businesses and helps develop other parts of a community like infrastructure (road and rail) and enhances the introduction of new technologies. All over the world it has been seen that mining increases employment in the area of the mine and also the level of skills of the local people. Mining is not just digging as stated by ACIL Tasman Ltd. (2006), but adds to essential support services including maintenance, warehousing, safety and first aid, human resources and administration. Last but not least, mining makes significant government tax payments, and if well managed it contributes to a diversification of the country's export pallet (Burley, 2000).

The poor image of mining is also affected by the negative image of small-scale and artisanal mining projects using rudimentary technologies, not possessing the financial nor the technological capacity of taking the right measures to minimize or avoid mining's environmental effects and health impacts (Aubynn, 2009). However, the main aspect in the debate on "yes or no" to mining, which until today has not been sufficiently addressed, is if large- and small-scale metallic mining can be 
made economical, social and environmental sound. Is it really impossible to bring into consonance the differences between the protagonists and the antagonists? Can mining for example through legislation, education and use of appropriate technologies not be transferred into a responsible economic activity with respect for the environment and with societal involvement (Maponga \& Ngorima, 2003)?

The authors of this paper discuss three fundamental pillars which, according to their belief, contribute to an improvement of the relationship between mining companies, the indigenous/local communities, the local and national government and the environmentalists. They are:

(i) Setting-up and maintaining an explanatory-based and transparent communication between stakeholders, on an equal basis in a language understood by all during the preparatory and implementation phases of mining;

(ii) Assessment and remediation of mine impacts with participation of environmentalists and in cooperation with the local scientific community, making mining during and after the lifetime of the project environmental more acceptable and contributing to the strengthening of the local research capacity; and

(iii) Offering the local communities support in developing economic activities such as the provision of support services and ecosystem restoration, activities which not only will reaffirm and help improving the self-esteem of the affected communities, but also generate employment throughout and likely also after the lifetime of the mine.

\section{DEVELOPMENT COMMUNICATION}

According to OXFAM (2009) the roots of the problems between local communities and mine companies are: (i) locals experience too few benefits from mining revenues; (ii) mining companies in the past made serious mistakes in their relationship with local communities; and (iii) local governments lack the capacity and political will to regulate the industry, manage local-conflicts and redress grievances. Other reasons of protest are that mining companies often violate the rights and endangers the way of life of local communities (Bebbington et al., 2008). In developing countries the indigenous peoples' rights are traditionally protected and guaranteed by national law. However, as a consequence of liberalization policies, governments redesigned mining laws to promote foreign investment, overruling in many cases the local peoples' rights (Harrison et al., 2003). This led to many illicit mining activities affecting the livelihoods and lands of the poorest people in and nearby the mining sites. The frustration of the locals is also fed by the failure of national governments to control if laws are respected and to apply meaningful and effective sanctions should foreign and local companies fail to do so. The confrontation is primarily driven by lack of knowledge, the belief and the fear that mining distorts the social fabric of local communities and the environment.

As stated by Hagerman (1996) a lot of development experts assume that the answer to the problem is to provide to locals better technology, but the real focus should be on improving communication. From the perspective of their relationship with mining companies, governmental and non-governmental organizations, villagers often feel frustrated that people are constantly coming in and telling them what their problem is and what the solutions to these problems are, without taking the time to really understand their situation. Another major problem that poisons the communication is the language used by each group of stakeholders. Government officials and representatives of the mine often use, mostly not intentionally, an academic jargon by which the representatives of the local communities are intimidated, reinforcing by them the impression that they are unable to participate.

Properly implemented communication helps in understanding the concerns and viewpoints of the stakeholders. Petterson et al. (2008) concluded that using a communication model that closely follows geological models for pollution issues helps local people better understanding the objectives and potential impacts of mining, and how by using science and technology effects can be prevented and restored. They found that the basic elements for good relationship are understanding of the local peoples' culture, customs, values, taboos and political-governance structures; involving indigenous people at every level of the communication process; issuing clear messages with outcome focus; using 
wherever and whenever possible face-to-face communication and simplified pictures for explaining complex matters; implementation throughout the mining process of a thorough follow-up and evaluation mechanism; and allocation of sufficient time to allow the process to be effective.

According to Sosa \& Keenan (2001), in addition to communication, a way to minimize the adverse social, cultural and economic effects of mining on local communities is through the negotiation of binding agreements. In Canada those agreements are called impact and benefit agreements (IBA) (Kennett, 1999). The main objective of IBAs is the establishment of formal relationships between mining companies and local communities in close cooperation with or under supervision of the local and national governments, addressing the measures ensuring that sufficient benefits drain to the local communities during and after closure of the mine and that the potential adverse effects of mining are properly addressed. Following Fidler \& Hitch (2007) essential steps in pursuing an IBA with the mining company are: (i) community councils or leaders should have a mandate of the community to negotiate with the mine company; (ii) the rules of the game for the negotiation should be embedded in a memorandum of understanding and signed by both parties as to avoid problems down the road; and (iii) IBA negotiations should be stretched over a sufficient long period as to allow communities to digest all the information about the project, allow them to seek advice from experts and make informed decisions. An indirect advantage for local communities to negotiate an IBA is the learning experience, whereas mining companies may view IBAs as a public relations practice that can help garner local support for their project. In addition, IBAs are for mining companies a way to secure a labor force at reasonable cost (Gogal et al., 2005).

\section{MINING AND THE ENVIRONMENT}

Gosar (2004) states that mining generates four categories of wastes: mine waste (overburden, barren rocks not containing ore), tailings (the waste of the beneficiation process which consists of non-value crushed ore), dump leach, heap leach or in-situ leach (remnants of the industrial process to leach gold from the ore), and mine water (infiltrating groundwater that must be evacuated to facilitate mining). These wastes give rise to a series of physical, pollution and health impacts. Among the physical impacts are the destruction of the natural ecosystem of the mining site, changes in landforms and the remaining of abandoned equipment, distortion of the natural water resources system, failure of structures and dams, and land degradation and instability. Pollution is due to drainage of chemical loaded effluents and increase in air-borne dust and other emissions, such as sulphur dioxide and nitrogen oxides from smelters. Health impacts on-site might be due to the physical risks and exposure to toxic materials, heat, noise, vibration and radiation, whereas off-side health impacts are the consequence of the contamination of surface and groundwater, and the atmosphere of surrounding areas.

The relation with environmentalists can according to Hudson et al. (1999) only improve explaining to them that the scientific and technological advances in recent time increased the understanding of the physical and chemical processes that cause undesired environmental consequences, and that research also led to the development of efficient mitigation and remediation approaches (Finnie et al., 2009; Hilson \& Monhemius, 2006; Mitich, 2010). Currently, research emphasis is also given to the reclamation of disturbed lands, the development of treatments and stabilization of metal-bearing soils; the prevention and treatment of contaminated water; the control of the amount and character of emissions to the atmosphere; and the minimization of wastes and the recycling of raw materials and by-products. Recently, techniques for the revegetation of native plants saw daylight and have been successfully applied in several abandoned industrial projects (Sim-Hee $e t$ al., 2004; Spiegel \& Veiga 2010; Tordoff et al., 2000). Future research should focus on the improvement and refinement of mitigation, remediation and conservation methods, as well as in making these methods more cost-effective.

Parallel to involving representatives of environmental pressure groups, it is recommended to engage also the local research community. Doing so offers a dual advantage, it is: (i) the local research community can participate in the baseline environmental impact assessment, the monitoring 
of mine impacts during the mining operation and the adaptation to local conditions of mitigation and remedial techniques; and (ii) it strengthens the research capacity of the local scientific community in environmental effect monitoring, data analysis and interpretation, and in all facets of land reclamation. In addition, the research community can help functionaries of the Ministry of Environment in improving the legal framework for the control of the environmental impact of mining and developing protocols that ensure that mining is conducted accordingly (Cao, 2007; Castro \& Sánchez, 2003; Mayes et al., 2009). A research-based monitoring, mitigation and remediation of mine impacts in participation with environmentalists and representatives of the mine company will enhance the probability that mining is conducted in an acceptable and sustainable way.

\section{CORPORATE SOCIAL MODEL}

Whereas in the northern hemisphere the society accepts that water, coal and minerals are state property and that the government has the right to exploit those resources for the benefit of the society, governments' also deployed legal instruments which assure that during and after the lifetime of the industrial development care is taken of a proper distribution of the benefits and the environment. The main differences with the developing countries is that the northern societies are more educated, better see the needs and benefits of mining, have more confidence that legal regulations are applied and controlled, and that mine companies under public pressure really attempt to make mining environmentally sound. Due to illiteracy and the much lower level of education, local communities are easily manipulated by lobbyist groups and eco-extremists and mining companies as well. In addition, locals in the south do not have much confidence in the authorities due to the fact that a legal framework to control mining operations is lacking or poorly developed, and also because governmental capacity to control mining hardly exists. Furthermore, local research capacity is weak to non-existing as a consequence of long-term insufficient national funding in $R \& D$, with the consequence that local communities are left over to pressure groups and consultants as to help them out.

Until very recently it was true that mine companies, with or without government support, returned only a fraction of the financial benefits as tax money, exploited and underpaid locals' working in the mine, paid little to no attention to the welfare of the locals' and the remediation of mine causing environmental and health hazards. After mine closure remnants, waste dumps and tailing dams were traditionally left untouched giving for many decades testimony of the mine activities, while the leaching of residual chemicals continued polluting the environment. To meet the increased pressure from opponents and respond to greater public scrutiny, mine companies recently developed global corporate social responsibility strategies as part of their global business strategies (Idemudia, 2009). In these strategies, a prominent place is given to the relationship with local communities, government functionaries, representatives of ecological pressure groups and the local scientific community.

Mine companies increasingly express the desire to cooperate with the local communities and employ locals for mine and logistic activities, but also to train them in new economic activities, which the villagers can develop independently to sustain economically family and community after mine closure (O'Faircheallaigh, 2010). In addition, mine companies seek cooperation with the local scientific community as to assist in the Baseline Environmental Assessment, and short- and long-term Environmental Assessment studies, and to examine potential techniques for the mitigation and remediation of environmental impacts._The voluminous list of scientific and technological published papers proves that today adequate mitigation and restoration approaches exist to avoid and/or minimize impacts, as well as to restore the mine site after mine closure (McLellan et al., 2009). The bottle-neck often is to make those techniques more cost-effective and suitable for the local conditions (Finnie et al., 2009).

To inspire and motivate the local community, a corporate social model can be developed in which locals initially participate, and later take the lead (McKinley, 2008). Activities executable by the villagers could be the provision of support services, being involved in the organization of mine- 
tourism in combination with eco-tourism, and participating in the implementation of mitigation, remediation and restoration activities. To this end the mine company with the support of the local scientific community and environmentalists' can train locals in economic activities grounded in landscape, flora and fauna, and equip the community with the necessary hardware and software tools. The scientific community with the assistance of ecologists can convert existing mitigation, remediation and ecological restoration techniques into small-scale activities that are technological executable by the local community; helping to improve the lack of knowledge regarding to the ecosystem services, mitigations and restoration. Doing so enables sharing in a constructive way project benefits with the villagers, preparing the community for the period after mine closure and caring for the viable nature and biosphere reserves of the mine site during operation and mine closure. After mine abandonment locals can continue developing these activities and become entrepreneurs in land conservation and the ecological restoration of degraded industrial and building sites.

Steps in ecosystem restoration in which locals can be involved encompass (Aguilar, 2001; Li, 2006; Straede \& Treue 2006; Zhang et al., 2007; Horowitz, 2008; Mendez \& Maier 2008):

(i) Commercialization of ecosystem goods and services;

(ii) Conservation of species and habitats;

(iii) Development and follow-up of field plots for the regeneration of natural plants and degraded soils;

(iv) Implementation of lime and other fertilizer experiments for the restoration of soil fertility;

(v) Setting-up of experiments testing substrate amelioration techniques and phytostablization mechanisms including precipitation of metals by bacteria and root exudates, bacterial uptake and sequestration of metals, and root uptake of metals; and

(vi) Implementation of landscaping trials, including the establishment of buffer zones around areas with industrial (mine) activity.

It is evident that the local communities lack the knowledge and skills to implement autonomously the above-cited activities, and therefore trainings appropriate to the educational level of local people have to be organized. Furthermore, to assure that the works of the local villagers are successful activities should be planned, coordinated and supervised by researchers with expertise in ecosystem restoration (Byers et al., 2006; Nare et al., 2006), eventually assisted by representatives of environmental organizations. Whereas in an initial phase funding for those activities have to come from the mine company, as time passes operations should be funded with support from the public sector and enterprises. The skills the local villagers acquire during the lifetime of the project should be used in the first place to restore the mine sites after closure; skills that also can be hired by the public/private sector for the restoration of degraded sites.

\section{CONCLUSIONS}

Today, in several Andean countries exists and environment of confrontation between the local governments, local communities and ecologists and the mining industry, notwithstanding the great economical potential of Andean mines. According to Wallace \& Hall-Wallace (2003) Andean mines account for more than 45 percent of the world's copper production, nearly 30 percent of the silver production, significant amounts of lead, zinc and gold and an array of industrial minerals and chemicals. Thanks to the mining of Andes mineral wealth several of the Andean countries generate a significant amount of their gross national product. In the confrontation, national governments are somehow undecided willing to give green light to industrial mining for the tax revenue, but at the other hand being reluctant because mining if not properly controlled can seriously damage the environment of the mine sites and the downstream areas.

Instead of provoking and sustaining confrontation, mine companies should in collaboration with all stakeholders turn industrial mining into an activity which is financially beneficial for the shareholders, the government and the local communities, and environmental sound. Introducing a corporate communication model can improve the communication with the villagers and the understanding of this group of what mining is about and how they can be involved in on-site and off- 
site activities. An important aspect in the corporate social model is the training and empowerment of the local communities in conservation and restoration techniques, capacities which they can develop throughout the mining operation and autonomous exploited thereafter. Doing so helps avoiding that locals employed by the mine suddenly become unemployed after mine closure, and it reinstates the communities in their role as guardians of earth's environment. The introduction of new technologies, eventually after adaptation by the local scientific community and ecologists, environmental mine impacts can be anticipated, mitigated or remediated. Involving the scientific community herein will help strengthening local and national R\&D capacity.

The development of an instruction manual of how in future in the Andean region micro-, smalland large-scale mining projects should be initiated, planned, explored, followed-up and closed, including guidelines for the protection of the environment during exploitation and the site-restoration after completion, would help in reducing, even preventing, the endless confrontations and discussions between those that are pro and contra mining. Such a manual could be instructive in the identification of flaws in the existing laws and procedures that regulate the exploitation of the Andean mineral resources and the legal monitoring. It is evident that such an instruction manual will only be meaningful when accompanied by the legal enforcement of a set of laws that control the exploitation of the mineral resources, regulates the economic benefits, the environmental impact and protection. Furthermore the law implementation should be monitored and controlled by government specialized inspection agency, sector ministries and local authorities, and the civil society. The latter consisting of representatives of professional organizations, associations and private entities can help in the monitoring of the law implementation. It is evident that the instruction manual for the guidance of mining activities at different scales is developed by competent multidisciplinary research groups/institutes in cooperation with the central Government, local authorities, the civil society and the mining sector.

\section{REFERENCES}

ACIL Tasman Ltd., 2006. Cost and benefits of CSIRO robotic mining $R \& D$. Economics Policy Strategy report to CSIRO's Lapsing Program Review. ACIL Tasman Ltd., Australia, 44 pp.

Aguilar, G., 2001. Access to genetic resources and protection of traditional knowledge in the territories of indigenous peoples. Environ. Sci. Policy, 4(4), 241-256.

Aubynn, A., 2009. Sustainable solution or a marriage of inconvenience? The coexistence of largescale mining and artisanal and small-scale mining on the Abosso Goldfields concession in Western Ghana. Resour. Policy, 34(1), 64-70.

Bebbington, A., D. Humphreys Bebbington, J. Bury, J. Lingan, J.P. Munoz, M. Scurrah, 2008. Mining and social movements: Struggles over livelihood and rural territorial development in the Andes. World Dev., 36(12), 2888-2905.

Burley, M.H.L., 2000. Impact equity and Canadian mining in Ecuador: A case study of stakeholder perspectives from communities, government and industry. MSc dissertation, School for Resource and Environmental Studies, Dalhousie University, Halifax, Nova Scotia, Canada, 306 pp.

Byers, J.E., K. Cuddington, C.G. Jones, T.S. Talley, A. Hastings, J.G. Lambrinos, J.A. Crooks, W.G. Wilson, 2006. Using ecosystem engineers to restore ecological systems. Trends Ecol. Evol., 21(9), 493-500.

Cao, X., 2007. Regulating mine land reclamation in developing countries: The case of China. Land Use Policy, 24(2), 472-483.

Castro, S.H., M. Sánchez, 2003. Environmental viewpoint on small-scale copper, gold and silver mining in Chile. J. Clean. Prod., 11(2), 207-213.

Downing, T.E., J. Moles, I. McIntosh, C. Garcia-Downing, 2002. Indigenous peoples and mining encounters: Strategies and tactics. IIED and WBCSD, Mining, Minerals and Sustainable Development, Report 57, 41 pp. 
Fidler, C., M. Hitch, 2007. Impact and benefit agreements: A contentious issue for aboriginal and environmental justice. Environments J., 35(2), 49-69.

Fields, S., 2006. The price of gold in Chile. Environ. Health Persp., 114(9), A536-A539.

Finnie, B., J. Stuart, L. Gibson, F. Zabriskie, 2009. Balancing environmental and industry sustainability: A case study of the US gold mining industry. J. Environ. Manage., 90(12), 3690-3699.

Gogal, S., R. Riegert, J. Jamieson, 2005. Aboriginal impact and benefit agreements: Practical considerations. Alta Law Rev., 43(1), 129-157.

González Zenteno, P., 1999. Tratamiento normativa de la fase minera post operacional en los países mineros Latinoamericanos y la planificación del cierre. IDRC-CIID. $174 \mathrm{pp}$. Available at https://idl-bnc.idrc.ca/dspace/bitstream/10625/30396/1/115216.pdf.

Gosar, M., 2004. Environmental impacts of mining. Materials and Geoenvironment, 51(4), 2097-2107.

Haarstad, H., A. Floysand, 2007. Globalization and the power of rescaled narratives: A case of opposition to mining in Tambogrande, Peru. Polit. Geogr., 26(3), 289-308.

Hagerman, E., 1996. Communicating with indigenous peoples: Lessons from Guyana. Université du Québec, Montréal, Canada, MSc dissertation, 107 pp.

Harrison, G.W., T.F. Rutherford, D.G. Tarr, 2003. Trade liberalization, poverty and efficient equity. J. Dev. Econ., 71(1): 97-128.

Hilson, G., 2002. An overview of land use conflicts in mining communities. Land Use Policy, 19(1): 65-73.

Hilson, G., A.J. Monhemius, 2006. Alternatives to cyanide in the gold mining industry: What prospects for the future? J. Clean. Prod., 14, 1158-1167.

Horowitz, L.S., 2008. "It's up to the clan to protect": Cultural heritage and the micropolitical ecology of conservation in New Caledonia. Soc. Sci. J., 45(2), 258-278.

Hudson, T.L., F.D. Fox, G.S. Plumlee,1999. Metal mining and the environment. AGI - Environment Awareness Series, 3, 68 pp. Available at http://www.agiweb.org/environment/publications/ metalsfull.pdf.

Idemudia, U., 2009. Assessing corporate-community involvement strategies in the Nigerian oil industry: An empirical analysis. Resour. Policy, 34(3), 133-141.

Kennett, S., 1999. A guide to impact and benefits agreements. Canadian Institute of Resources Law, ISBN-13: 978-0-919269-48-4, $120 \mathrm{pp}$.

Kumah, A., 2006. Sustainability and gold mining in the developing world. J. Clean. Prod., 14(3): 315-323.

Li, MS., 2006. Ecological restoration of mineland with particular reference to the metalliferous mine wasteland in China: A review of research and practice. Sci. Total Environ., 357(1), 38-53.

Maponga, O., C.F. Ngorima, 2003. Overcoming environmental problems in the gold panning sector through legislation and education: the Zimbabwean experience. J. Clean. Prod., 11(2): 147-157.

Mayes, W.M., D. Johnston, H.A.B. Potter, A.P. Jarvis, 2009. A national strategy for identification, prioritization and management of pollution from abandoned non-coal mine sites in England and Wales. I. Methodology development and initial results. Sci. Total Environ., 407, 5435-5447.

McColl, G.D., 1980. The mining industry and the natural environment. Resour. Policy, 6(2), 153-165.

McKinley, A., 2008. The drivers and performance of corporate environmental and social responsibility in the Canadian mining industry. University of Toronto, Geography Department and Center for Environment, MA dissertation, $238 \mathrm{pp}$.

McLellan, B.C., G.D. Corder, D. Giurco, S. Green, 2009. Incorporating sustainable development in the design of mineral processing operations - Review and analysis of current approaches.

J. Clean. Prod., 17(16), 1414-1425. 
Mendez, M.O., R.M. Maier, 2008. Phytostabilization of mine tailings in arid and semiarid environments: An emerging remediation technology. Environ. Health Persp., 116(3), 278-283.

Mitich, M., 2010. Sustainable approaches to a reform of coal mining industry in Serbia. J. Sustain. Dev., 3(1), 61-68.

Mudd, G.M., 2007. Global trends in gold mining: Towards quantifying environmental and resource sustainability. Resources Policy, 32(1), 42-56.

Nare, L., D. Love, Z. Hoko, 2006. Involvement of stakeholders in the water quality monitoring and surveillance system: The case of Mzingwane Catchment, Zimbabwe. Physics and Chemistry of the Earth, Parts $A / B / C, 31(15-16), 707-712$.

O'Faircheallaigh, C., 2010. Public participation and environmental impact assessment: Purposes, implications, and lessons for public policy making. Environ. Impact Assess., 30(1): 19-27.

OXFAM, 2009. Mining conflicts in Peru: Condition critical. 14 pp. Available at http://www.oxfamamerica.org/static/media/files/mining-conflicts-in-peru-condition-critical.pdf.

Petterson, M.G., D. Tolia, S.J. Cronin, R. Addison, 2008. Communicating geoscience to indigenous people: examples from the Solomon Islands. Geological Society, London, Special Publications 305, 141-161.

Pick, W., S. Naidoo, F. Ajani, V. Onwukwe, R. Hansia, O. Bielu, 2003. Prevalence of alcohol and cannabis use and reported knowledge, attitudes and practice regarding its relationship with health and safety on mines in South Africa. Safety in Mines Research Advisory Committee: Wits School of Public Health, Health 712, Johannesburg, South Africa, 85 pp.

Sim-Hee, H., L. Jae-Cheon, J. Suk-Seong, K. Pan-Gi, 2004. Composted sewage sludge can improve the physiological properties of Betula schmidtii grown in tailings. J. Plant Biol., 47(2), 99-104.

Sosa, I., K. Keenan, 2001. Impact benefit agreements between aboriginal communities and mining companies: Their use in Canada. 29 pp. Available at http://www.cela.ca/files/ uploads/IBAeng.pdf.

Spiegel, S.J., M.M Veiga, 2010. International guidelines on mercury management in small-scale gold mining. J. Clean. Prod., 18(4), 375-385.

Straede, S., T. Treue, 2006. Beyond buffer zone protection: A comparative study of park and buffer zone products' importance to villagers living in its buffer zone. J. Environ. Manage., 78(3), 251267.

Tarras-Wahlberg, N.H., A. Flachier, S.N. Lane, O. Sangfors, 2001. Environmental impacts and metal exposure of aquatic ecosystems in rivers contaminated by small scale gold mining: The Puyango River basin, southern Ecuador. Sci. Total Environ., 278(1), 239-261.

Tordoff, G.M., A.J.M. Baker, A.J. Willis, 2000. Current approaches to the revegetation and reclamation of metalliferous mine wastes. Chemosphere, 41(1-2), 219-228.

Williams, M., 1990. Mining future - Environmentalists try to stave off rush for State's minerals. Seattle Times, Sunday, December 30, 5 pp. Available at http://community.seattletimes.nwsource.com/archive/?date=19901230\&slug=1111986.

Wallace, T.C., M.K. Hall-Wallace, 2003. Minerals of the Andes: Emeralds, gold, and silver from the sky. Rocks \& Minerals, 78(1), 28 pp. Available at http://www.researchgate.net/publication/ 233151998_Minerals_of_the_Andes_Emeralds_Gold_and_Silver_from_the_Sky.

Zhang, L., Q. Liu, N.W. Hall, Z. Fu, 2007. An environmental accounting framework applied to green space ecosystem planning for small towns in China as a case study. Ecol. Econ., 60(3), 533-542. 